\title{
Occurrence and Genetic Diversity of Grapevine berry inner necrosis virus from Grapevines in China
}

X. D. Fan, National Center for Eliminating Viruses from Deciduous Fruit Tree, Research Institute of Pomology, Chinese Academy of Agriculture Sciences, Liaoning, Xingcheng 125100, People's Republic of China; and National Key Laboratory of Agromicrobiology, College of Plant Science and Technology, Huazhong Agricultural University, Wuhan, Hubei 430070, People's Republic of China; Z. P. Zhang, F. Ren, G. J. Hu, J. Zhou, and Z. N. Li, National Center for Eliminating Viruses from Deciduous Fruit Tree, Research Institute of Pomology, Chinese Academy of Agriculture Sciences; G. Wang, National Key Laboratory of Agromicrobiology, College of Plant Science and Technology, Huazhong Agricultural University; and Yafeng Dong, National Center for Eliminating Viruses from Deciduous Fruit Tree, Research Institute of Pomology, Chinese Academy of Agriculture Sciences

\begin{abstract}
To investigate the prevalence and genetic diversity of Grapevine berry inner necrosis virus (GINV) in China, 195 grapevine samples from 15 Chinese provinces and regions were tested using reverse-transcription polymerase chain reaction. The samples included symptomatic and asymptomatic cultivars, with $35.9 \%$ (70 of 195) of samples testing positive for GINV. Seventeen samples had obvious ring spot symptoms, and $94.1 \%$ ( 16 of 17 ) tested positive for GINV, suggesting that GINV may be highly associated with the ring spot symptom. The genetic diversity of

GINV isolates was analyzed based on the partial nucleotide and amino acid sequences of the coat protein (CP) and movement protein (MP) genes. Phylogenetic analyses of the MP and CP gene sequences divided the GINV isolates into three groups. The majority of the Chinese isolates were in groups 1 and 2, and only one Chinese isolate, along with a previously reported Japanese isolate, was in group 3. This is the first report on the genetic diversity of GINV isolates and their prevalence and distribution in China.
\end{abstract}

Grapevine berry inner necrosis, which was first found in Japan in 1984 and was originally named as grapevine mosaic disease, can cause severe damage to grapevines and spreads naturally in fields. It was previously reported as the most economically important viral disease of grapevine in Yamanashi, Japan (Kunugi et al. 2000; Terai et al. 1993). The expression of symptoms varies depending on the grape cultivar; in susceptible cultivars, the diseased grapevines grow less vigorously and sprout late in spring, and the vines show inner necrosis in shoots, shortening internodes, and various patterns of yellow discoloration on the leaves (Terai et al. 1993). Berries on affected grapevines are small, and show discoloration on the rind and necrosis of the flesh. The causal virus of grapevine berry inner necrosis has been identified and named Grapevine berry inner necrosis virus (GINV), belonging to the genus Trichovirus (Yoshikawa et al. 1997). The genome of GINV contains three open reading frames and two untranslated regions at the $5^{\prime}$ and $3^{\prime}$ termini. The proteins encoded by the three open reading frames of GINV are RNA polymerase, movement protein (MP), and coat protein (CP). GINV can be transmitted by grapevine erineum mites in the field (Kunugi et al. 2000).

After first being reported in Japan, GINV has since been found only in China. The Chinese GINV isolate was identified by small RNA sequencing in a 'Beta' grapevine rootstock displaying serious chlorotic mottling and ring spot in Liaoning Province, China (Fan et al. 2016b). The symptoms were originally thought to be caused by Grapevine fanleaf virus (GFLV) or another nepovirus. In addition to the Beta grapevine, other rootstocks and cultivars also displayed chlorotic mottling and ring spot in the field. Because symptom phenotypes depend on various factors, including the resistance level of the grapevine cultivar, the environment, and different viral different variants, it is possible that other cultivars that did not display

Corresponding author: Y. Dong; E-mail: yfdong1234@ 163.com

*The $\boldsymbol{e}$-Xtra logo stands for "electronic extra" and indicates that one supplementary table and six supplementary figures are published online.

Accepted for publication 5 August 2016.

C) 2017 The American Phytopathological Society symptoms in the field were infected with GINV. Because of GINV's serious impact on grapevines, it is necessary to fully investigate the occurrence and prevalence of GINV in the symptomatic and asymptomatic grape cultivars in China.

After the transmission of viruses by insect vectors, the exchange and propagation of virus-infected seedlings is the major reason for viral epidemics. Planting virus-free seedlings remains the essential measure to control viral diseases, and virus detection is a crucial step for the production of virus-free seedlings. As a newly identified virus in China, further verification is needed as to whether GINV should be added to the list of viral pathogens whose presence must be tested for to achieve grapevine certification in China. The priority is to identify the genetic diversity of GINV isolates, which will help establish molecular detection methods for GINV which can be used for further surveys of GINV in China.

At present, only two GINV isolates, Japanese isolate D88448 and Chinese isolate LN_BETA_RS (KU234316), have been reported. The genetic diversity of GINV isolates remains unknown, which is not conducive to the development of molecular diagnostic methods and the deep studies of GINV. In this study, we applied reversetranscription polymerase chain reaction (RT-PCR) and RT-nested (n)PCR to detect GINV in 195 grapevine samples collected from 15 provinces and regions of China. The prevalence and occurrence of GINV in different provinces and regions were surveyed, and the genetic diversity of the Chinese GINV isolates was analyzed based on partial MP and $\mathrm{CP}$ gene sequences.

\section{Materials and Methods}

Plant materials. To investigate the prevalence and genetic diversity of GINV, 195 grapevine samples were collected from 15 provinces and regions in China. The samples were from different commercial vineyards and one varietal collection of Vitis vinifera in Liaoning province. The samples included 53 different cultivars, 123 Eurasian grape cultivars (Vitis vinifera L.), 20 hybrids of European and American grape $(V$. vinifera $\times V$. labrusca), 14 hybrids of European and Amur grape ( $V$. vinifera $\times V$. amurensis), and 38 others (including some American rootstocks and hybrids). According to their applications, the samples included 93 wine grape varieties, 71 table grape varieties, and 22 rootstocks. The dormant canes from these samples and a virus-eliminated grapevine (as a negative control) were collected and kept at $4{ }^{\circ} \mathrm{C}$ until the extraction of total RNA. 
RT-PCR detection. RNA was extracted from phloem scrapings (50 mg) using a previously reported method (MacKenzie et al. 1997), with some modifications (Fan et al. 2015b). RNA extract ( $5 \mu \mathrm{l}$ ) was mixed with $1 \mu \mathrm{l}$ of random hexamers primer (Sangon Biotech, Shanghai, China) and $9 \mu \mathrm{l}$ of RNase-free water, denatured at $70^{\circ} \mathrm{C}$ for $5 \mathrm{~min}$, and kept on ice for $3 \mathrm{~min}$. Then, $0.5 \mu \mathrm{l}(200 \mathrm{U} / \mu \mathrm{l})$ of Moloney Murine Leukaemia Virus (M-MLV) RT (Invitrogen, Carlsbad, CA), $5 \mu \mathrm{l}$ of $5 \times$ M-MLV buffer, $1.25 \mu l$ of $10 \mathrm{mM}$ dNTP, and $3.25 \mu \mathrm{l}$ of RNA-free water were added and the reaction was incubated at $37^{\circ} \mathrm{C}$ for $10 \mathrm{~min}$ and at $42^{\circ} \mathrm{C}$ for $50 \mathrm{~min}$, before being denatured at $70^{\circ} \mathrm{C}$ for $5 \mathrm{~min}$. Single PCR was performed in a $25-\mu \mathrm{l}$ reaction mixture containing $2.5 \mu \mathrm{l}$ of the RT product, $2.5 \mu \mathrm{l}$ of $10 \times$ reaction buffer, $0.5 \mu \mathrm{l}$ of $10 \mathrm{mM} \mathrm{dNTP}, 0.5 \mu \mathrm{l}$ of $10 \mathrm{mM}$ each primer (Table 1), and $0.15 \mu \mathrm{l}$ of rTaq enzyme at $5 \mathrm{U} / \mu \mathrm{l}$ (Takara, Dalian, China). The cycling parameters were set as follows: preactivation at $95^{\circ} \mathrm{C}$ for $3 \mathrm{~min}$ followed by 35 cycles of denaturation $(30 \mathrm{~s}$ at $\left.95^{\circ} \mathrm{C}\right)$, annealing $(30 \mathrm{~s}$ at certain temperature for each primer), and extension $\left(1 \mathrm{~min}\right.$ at $\left.72^{\circ} \mathrm{C}\right)$. Initial RT-PCR products were diluted to 1:10 before use as templates for RT-nPCR. For RT-nPCR, all the reaction conditions were the same as those for RT-PCR, except that the cycle number changed to 30 . PCR assays were carried out to amplify the different gene fragments of GINV using different primer sets (Table 1). The 585-, 968-, and 954-bp fragments were amplified by conventional PCR using the following primers: GINVCP1A/1B, based on the GINV CP gene; GINVMP1A/1B, based on the GINV MP gene; and GINVMPCP1A/1B, based on a segmental fragment covering the $\mathrm{MP}$ and $\mathrm{CP}$ genes. Another primer pair, GINVMPn1A/1B, was used in a second $\mathrm{nPCR}$, having the PCR product generated in the first-round PCR by the primer pair GINVMP1A/1B as the template. All 195 grapevine samples were tested for GINV using the primer pairs GINVCP1A/1B, GINVMP1A/1B, and GINVMPn1A/1B. Only 23 grapevine samples were tested for GINV using the primer pair GINVMPCP1A/1B. In addition, 25 of 27 symptomatic grapevine samples were used for the detection for GFLV and Grapevine Pinot gris virus (GPGV). The PCR and nPCR detection of GFLV were performed as described previously (Zhou et al. 2015). The PCR detection of GPGV can also be carried out as described previously (Fan et al. 2016a).

Genetic diversity. The GINV amplicons were cloned individually into the Zero Background pTOPO-TA vector (Aidlab, Beijing). At least three clones were sequenced, and a consensus sequence was derived when the three independent clones showed $\geq 98 \%$ identity, thus eliminating in vitro RT-PCR errors. If the three initially sequenced clones showed $<98 \%$ nucleotide sequence identity, then additional clones were sequenced to investigate the possible occurrence of mixtures of distinct sequence variants within individual grapevines. Multiple alignments of nucleotides and protein sequence identities were obtained using the ClustalW2 program (http://www.ebi.ac.uk/ Tools/msa/clustalw2/).

Phylogenetic analysis. Aligned sequences of the MP and CP genes were scanned using seven recombination detection programs (RDP, BOOTSCAN, SISCAN, SEQ, GENECONV, LARD, and MAXCHI) implemented in the program RDP 3 (Martin et al. 2010) to detect putative recombination events. Neighbor-joining phylogenetic trees were constructed for the CP and MP genes, independently, with the MEGA 6.0 software package (Tamura et al. 2013), using the model of best fit for the sequence data set and 1,000 bootstraps.
Sequences obtained in this study and others obtained from GenBank were used in the analysis. The sequences generated in this study are listed in Table 2.

\section{Results}

GINV detection results using different primers. RT-PCR assays were performed to detect GINV in 195 samples collected from 15 provinces and regions, with 45 of 195 (23.0\%) and 40 of 195 (20.5\%) samples testing positive for GINV using the primers GINVCP1A/1B and GINVMP1A/1B, respectively, in the conventional PCR. Furthermore, 65 of $195(33.3 \%)$ samples tested positive for GINV by the $\mathrm{nPCR}$ method using the primer GINVMPn1A/1B, with the products generated by the primer GINVMP1A/1B as templates. Among them, 17 samples which tested negative for GINV using the primers GINVCP1A/1B and GINVMP1A/1B by conventional PCR were confirmed to be positive using the primer GINVMPn1A/1B by $\mathrm{nPCR}$. The PCR results using the primers GINVMP1A/1B and GINVMPn1A/1B can be found in Supplementary Figures S1 to S6. In addition, 18 of 23 samples tested positive using the primer GINVMPCP1A1B. The general incidence of GINV was $35.9 \%$ (70 of 195) using all of the above primer sets (Supplementary Table S1).

Occurrence and prevalence of GINV in China. Samples from 10 of 15 provinces and regions were found to be infected with GINV (Fig. 1). In all, $81.0 \%$ (17 of 21), 66.7\% (14 of 21), 52.6\% (10 of 19), $39.6 \%$ ( 19 of 48 ), $25 \%$ ( 2 of 8 ), and $6.5 \%$ ( 3 of 46 ) samples tested positive for GINV in grapevines from Ningxia, Beijing, Xinjiang, Liaoning, Gansu, and Shandong, respectively (Table 3).

In total, 24 of 53 different cultivars tested positive for GINV. There was a higher incidence of GINV $(30.1 \%$; 37 of 123) in grapevines belonging to $V$. vinifera $\mathrm{L}$., compared with incidences of $15 \%$ (3 of 20) in grapevines of species $V$. vinifera and $V$. labrusca. No GINV isolate was found in the 14 'Beibinghong' grapevines belonging to $V$. vinifer $a$ and $V$. amurensis. There were incidences of $28.2 \%$ ( 20 of 71 ), $24.7 \%$ (23 of 93), and $27.3 \%$ (6 of 22) in table grapevines, wine grapevines, and rootstocks, respectively.

In this study, only 27 grapevines belonging to 20 cultivars showed obvious chlorotic mottling in the spring. In these samples, 17 grapevines belonging to 13 cultivars also displayed obvious ring spot in summer, including some popular grapevine rootstocks and cultivars such as Beta, 'Riparia', 'Thompson Seedless', 'Muscat Hamburg', 'Red Globe', 'Cabernet Sauvignon', 'Hongshuangwei', 'Guifeimeigui', and 'Zixiangwuhe'. Among these, Beta and Riparia grapevines were planted as virus-eliminated rootstocks in the seedling breeding garden in 2011 and did not show obvious symptoms in the past 3 years but were found to show ring spot symptoms recently and tested positive for GINV. In the 17 samples showing ring spot, $94.1 \%$ (16 of 17) samples tested positive for GINV, 17.6\% (3 of 17) tested positive for GPGV, and none of the samples tested positive for GFLV. These results suggested that GINV may be associated with ring spot on the leaves of some of the susceptible cultivars.

Genetic diversity of GINV in tested grapevine samples. The $\mathrm{CP}$ sequence from 16 GINV isolates, MP sequence from 19 isolates, and MP-CP sequences from 17 isolates were obtained (from different geographical origins and different cultivars) to analyze the genetic diversity of GINV isolates. The sequences of these isolates were deposited in GenBank (Table 2). The CP and MP sequences were aligned

Table 1. Sequences of primer sets used for the polymerase chain reaction (PCR) and nested PCR detection of Grapevine berry inner necrosis virus isolates

\begin{tabular}{llcc}
\hline Primer & \multicolumn{1}{c}{ Sequences $\left(\mathbf{5}^{\prime} \mathbf{- 3}^{\prime}\right)$} & Genomic region & Size $(\mathbf{b p})$ \\
\hline GBINCP1A & ATGTCGATMAGRCAGGAATTG & CP & 585 \\
GBINCP1B & CATAGTAAAAGCACCCTCGCT & $\ldots$ & $\ldots$ \\
GBINMP1A & WMGKGTTTCTGGGAAGATTGC & MP & $\ldots$ \\
GBINMP1B & KACSAGATCCCTCAATTCCTG & $\ldots$ & $\ldots$ \\
GBINMPn1A & AATTGCGAATCTACCCTCAAG & MP & $\ldots$ \\
GBINMPn1B & CTCAATTCCTGYCTKATCGAC & $\ldots$ & $\ldots$ \\
GBINMPCP1A & GACCAATTTCAARATTGATGG & MP+CP & \\
GBINMPCP1B & ATTACATAGTAAAAGCACCCTCGC & $\ldots$ & $\ldots$ \\
\hline
\end{tabular}


and adjusted into identical lengths. In total, $32 \mathrm{CP}$ sequences and 37 MP sequences were used to analyze the genetic diversity of GINV isolates (Fig. 2). The $\mathrm{CP}$ sequences showed identities ranging from 78.46 to 100 and 85.57 to $100 \%$ at the nucleotide and amino acid levels, respectively. The MP gene sequences showed identities ranging from 68.84 to 100 and 65.91 to $100 \%$ at the nucleotide and amino acid levels, respectively. The overall mean value of the nucleotide diversity in all of the obtained GINV isolates was $0.204 \pm 0.041$ for CP genes and $0.377 \pm 0.075$ for MP genes.

For most of those isolates, the three initially sequenced clones within a single grapevine showed $>98.0 \%$ identity, except for isolates from samples NX-Cas-5 (CP gene), HB-Cas (CP gene), NX-Cas-3 (MP gene), NX-Cas-6 (MP gene), NX-Cha (MP gene), BJ-Cas-1 (MP gene), LN-426-2 (MP gene), and XJ-Cas (MP gene) (Fig. 2 ). Thus, more clones were sequenced to determine the variant type within those isolates, except for NX-Cas-6. The sequence analyses showed that all of these isolated clones consisted of two variant types belonging to group 1 and group 2 . Variants belonging to group 1 were predominant in isolates NX-Cas-5 (eight group 1, one group 2), HBCas (five group 1, one group 2), LN-426-2 (five group 1, two group 2 ), and XJ-Cas (six group 1, four group 2), whereas variants belonging to the group 2 were predominant in the isolate NX-Cas-3 (one

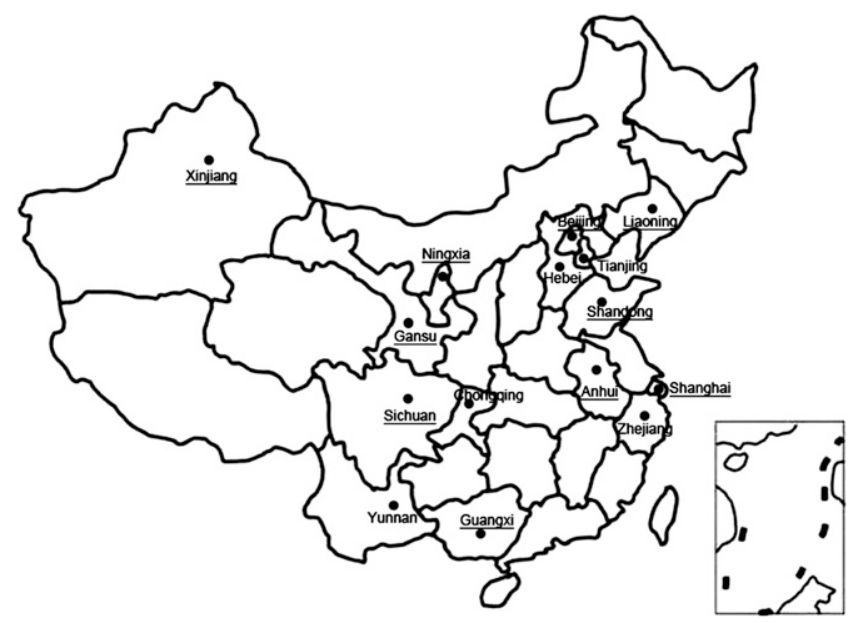

Fig. 1. Map of China indicating the provinces and regions (marked with a black dot) where grapevines samples were from for testing for the presence of Grapevine berry inner necrosis virus (GINV). Some provinces and regions were underlined, indicating the existence of GINV.

Table 2. Isolate ID, source, cultivar, host species, GenBank accession number, and other details of Grapevine berry inner necrosis virus isolates generated and analyzed in this study

\begin{tabular}{|c|c|c|c|c|c|}
\hline Isolate ID & Source & Cultivar & Host species, type ${ }^{a}$ & Genomic region $^{\mathbf{b}}$ & GenBank accession number \\
\hline $\mathrm{BJ}-\mathrm{CaF}-1$ & Beijing & Cabernet Franc & V. vini., wine & MP & KU248056 \\
\hline $\mathrm{BJ}-\mathrm{CaF}-2$ & Beijing & Cabernet Franc & V. vini., wine & $\mathrm{CP}$ & KU248011 \\
\hline BJ-CaS-1 & Beijing & Cabernet Sauvignon & V. vini., wine & $\mathrm{CP}, \mathrm{MP}$ & KU248012, KU248057-KU248064 \\
\hline BJ-CaS-2 & Beijing & Cabernet Sauvignon & V. vini., wine & MP & KU248065 \\
\hline BJ-Cha & Beijing & Chardonnay & V. vini., wine & $\mathrm{CP}$ & KU248010 \\
\hline BJ-MuH & Beijing & Muscat Hamburg & V. vini., table & $\mathrm{MP}, \mathrm{MP}+\mathrm{CP}$ & KU248066, KU248076 \\
\hline GS-JX & Gansu & Jingxiu & V. vini., table & $\mathrm{CP}$ & KU247984 \\
\hline HB-CaS & Hebei & Cabernet Sauvignon & V. vini., wine & $\mathrm{CP}$ & KU247989-KU247994 \\
\hline LN-DLW & Liaoning & Delaware & Hybrid, table & $\mathrm{CP}, \mathrm{MP}, \mathrm{MP}+\mathrm{CP}$ & KU247997, KU248013, KU248071 \\
\hline LN-Vict & Liaoning & Victoria & V. vini., table & $\mathrm{MP}, \mathrm{MP}+\mathrm{CP}$ & KU248014, KU248074 \\
\hline LN-ANSJ & Liaoning & Ayaneskeal & Hybrid, table & $\mathrm{MP}, \mathrm{MP}+\mathrm{CP}$ & KU248015, KU248072 \\
\hline LN-426 & Liaoning & 426 & Unknown & $\mathrm{CP}, \mathrm{MP}$ & KU247998, KU248016 \\
\hline LN-426-2 & Liaoning & 426 & Unknown & MP & KU248038-KU248044 \\
\hline LN-AuS & Liaoning & Autumn seedless & V. vini., table & MP & KU248067 \\
\hline LN-Beta1 & Liaoning & Beta & Hybrid, root & $\mathrm{MP}+\mathrm{CP}$ & KU248079 \\
\hline LN-Beta2 & Liaoning & Beta & Hybrid, root & $\mathrm{MP}+\mathrm{CP}$ & KU248081 \\
\hline LN-Beta3 & Liaoning & Beta & Hybrid, root & $\mathrm{MP}+\mathrm{CP}$ & KU248080 \\
\hline LN-GFMG & Liaoning & Guifeimeigui & V. vini., table & $\mathrm{MP}+\mathrm{CP}$ & KU248075 \\
\hline LN-Herb & Liaoning & Herbert & V. vini.-V. labrusca, table & $\mathrm{MP}+\mathrm{CP}$ & KU248069 \\
\hline LN-Mol & Liaoning & Moldova & Hybrid,, table & $\mathrm{MP}+\mathrm{CP}$ & KU248078 \\
\hline LN-MuH & Liaoning & Muscat Hamburg & V. vini., table & $\mathrm{MP}+\mathrm{CP}$ & KU248070 \\
\hline LN-Riparia1 & Liaoning & Riparia1 & $V$. rip., root & $\mathrm{MP}+\mathrm{CP}$ & KU248082 \\
\hline LN-Riparia2 & Liaoning & Riparia 2 & V. rip., root & $\mathrm{MP}+\mathrm{CP}$ & KU248083 \\
\hline LN-Riparia3 & Liaoning & Riparia 3 & V. rip., root & $\mathrm{MP}+\mathrm{CP}$ & KU248084 \\
\hline LN-RDX & Liaoning & Roudingxiang & V. vini.-V. lab., table & $\mathrm{MP}+\mathrm{CP}$ & KU248068 \\
\hline NX-Cha & Ningxia & Chardonnay & V. vini., wine & MP & KU248018-KU248025 \\
\hline NX-RG & Ningxia & Red Globe & V. vini., table & $\mathrm{CP}$ & KU247985 \\
\hline NX_CaG-1 & Ningxia & Cabernet Gernischt & V. vini., wine & $\mathrm{CP}$ & KU247986 \\
\hline NX-CaS-1 & Ningxia & Cabernet Sauvignon & V. vini., wine & $\mathrm{CP}$ & KU247987 \\
\hline NX-CaG-2 & Ningxia & Cabernet Gernischt & V. vini., wine & $\mathrm{CP}$ & KU247988 \\
\hline NX-MeL & Ningxia & Merlot & V. vini., wine & $\mathrm{CP}$ & KU247995 \\
\hline NX-CaS-2 & Ningxia & Cabernet Sauvignon & V. vini., wine & $\mathrm{CP}$ & KU247996 \\
\hline NX-CaS-3 & Ningxia & Cabernet Sauvignon & V. vini., wine & MP & KU248026-KU248032 \\
\hline $\mathrm{NX}-\mathrm{CaF}$ & Ningxia & Cabernet Franc & V. vini., wine & MP & KU248033 \\
\hline NX-CaS-4 & Ningxia & Cabernet Sauvignon & V. vini., wine & MP & KU248034 \\
\hline NX-CaS-5 & Ningxia & Cabernet Sauvignon & V. vini., wine & $\mathrm{CP}, \mathrm{MP}$ & KU247999-KU248007, KU248035 \\
\hline NX-CaS-6 & Ningxia & Cabernet Sauvignon & V. vini., wine & MP & KU248036-KU248037 \\
\hline SD-Gam & Shandong & Gamay & V. vini., wine & MP & KU248017 \\
\hline XJ-Zxwh & Xinjiang & Zixiangwuhe & V. vini., table & $\mathrm{MP}+\mathrm{CP}$ & KU248073 \\
\hline XJ-Ths & Xinjiang & Thompson Seedless & V. vini., table & $\mathrm{CP}, \mathrm{MP}, \mathrm{MP}+\mathrm{CP}$ & KU248008, KU248045, KU248077 \\
\hline $\mathrm{XJ}-\mathrm{CaS}$ & Xinjiang & Cabernet Sauvignon & V. vini., wine & $\mathrm{CP}, \mathrm{MP}$ & KU248009, KU248046-KU248055 \\
\hline
\end{tabular}

\footnotetext{
${ }^{a}$ Species: Vitis vinifera L. (V. vini.), Vitis hybrid (Hybrid), V. labrusca (V. lab.), and Vitis riparia Michamx (V. rip.). Grape types: wine, table, and rootstock (root).
}

${ }^{\mathrm{b}} \mathrm{MP}=$ movement protein and $\mathrm{CP}=$ coat protein 
group 1, six group 2). The isolates NX-Cha and BJ-Cas-1 had the same number of variants in groups 1 and 2.

Phylogenetic analysis of GINV isolates from China. The $32 \mathrm{CP}$ sequences and $37 \mathrm{MP}$ sequences, together with $\mathrm{CP}$ and MP sequences of the Chinese isolate LN_BETA_RS (GenBank ID: KU234316) and a Japanese isolate (GenBank ID: D88448), were used to detect putative recombination events and reconstruct the phylogeny. The results showed that there were no recombination events in the CP and MP gene sequences using one of seven detection method implemented in the program RDP 3 . The phylogenetic analysis results revealed the existence of three well-defined clusters according to the $\mathrm{CP}$ and MP-based phylogenetic trees (Fig. 2). The major Chinese isolates belonged to groups 1 and 2, and the Chinese isolate LN-Beta2 and the Japanese isolate were in group 3 . For the $\mathrm{CP}$ gene, the values of genetic distances within groups 1,2 , and 3 were $0.027 \pm 0.004,0.012 \pm 0.003$, and $0.016 \pm 0.005$, respectively. The genetic distances between variant groups ranged from $0.340 \pm 0.071$ to $0.503 \pm 0.107$. For the MP gene, the values of genetic distances within groups 1,2 , and 3 were $0.019 \pm$ $0.004,0.020 \pm 0.003$, and $0.017 \pm 0.006$, respectively. The genetic distances between the MP gene variant groups ranged from $0.634 \pm 0.140$ to $1.024 \pm 0.265$.

\section{Discussion}

Grapevine viral diseases are a major threat to the grapevine industry. Thus far, 13 viral species have been reported in China, including Grapevine leafroll-associated virus (GLRaV)-1 to -4 and -7 (Fan et al. 2015a,b; Farooq et al. 2013; Liu et al. 2013; Lyu et al. 2013; Pei et al. 2010), Grapevine rupestris stem pitting-associated virus (GRSPaV; Hu et al. 2015), Grapevine fleck virus, GFLV (Zhou et al. 2015), Grapevine virus A (Wang et al. 2011), Grapevine virus $B$ (Hu et al. 2014), Grapevine virus E (Fan et al. 2013), GPGV (Fan et al. 2016a), and the recently reported GINV (Fan et al. 2016b). Among these viruses, GPGV and GINV were recently identified in grapevines having fanleaf disease-like symptoms (including chlorotic mottling and ring spot) in China; however, GFLV has never been found in these diseased samples in the current survey. Thus, to guarantee the clean status of grapevine seedlings, it is necessary to perform further studies on the prevalence and occurrence of these newly found viruses and, especially, GINV, which had been previously reported as an economically important virus in Japan (Yoshikawa et al. 1997) and was also found to be associated with grapevine ring spot in China (Fan et al. 2016b). In the present study, GINV was common in grapevine cultivars in different provinces and regions of China and had a relatively high incidence $(35.9 \%$, 70 of 195) in tested grapevines. There was a $94.1 \%$ (16 of 17) incidence of GINV in samples displaying ring spot, suggesting that GINV may be highly associated with that symptom, which corroborated a previous study (Fan et al. 2016b). Thus, GINV should be considered as an addition to the list of viral pathogens whose presence must be tested for to achieve grapevine certification in China.

At present, RT-PCR is still one of the most common virus detection methods. Previous studies on the PCR detection of several grapevine viruses, including GRSPaV, GLRaV-1, and GLRaV-7, showed that different primers, designed against different regions of the viral genome, can have different amplification effects (Fan et al. 2015b; Lyu et al. 2014; Nolasco et al. 2000; Terlizzi et al. 2011). The present study also showed that several primers designed against different regions of GINV had some inconsistent detection results. These inconsistencies are not unusual because these primers were designed based on a limited number of GINV sequences and may have different amplification abilities for a range of GINV isolates. Some grapevine viruses can be distributed unevenly in plant tissue, with low concentrations, making viral detection more difficult. Thus, more sensitive detection methods need to be used to improve detection sensitivity and avoid false-negative results. To avoid false-negative results, we further detected GINV using the nPCR method with the primer pair GINVMPn1A/1B, showing that $n P C R$ could result in more GINV-positive results. The nPCR method had been carefully used in the detection of several grapevine viruses and had a higher sensitivity than the conventional PCR (Fan et al. 2015a,b; Farooq et al. 2013). A previous study also showed that nPCR and RT-loop-mediated isothermal amplification methods may have similar sensitivities in the detection of GLRaV-3 type 3 (Walsh and Pietersen 2013).

The spread of grapevine viruses in the field is mainly caused by grafting and insect vectors. The use of virus-free plant materials can greatly reduce the risk of viral infections. However, insect vectors carrying viruses can transmit them, reinfecting the plant materials. Obvious chlorotic mottling and ring spot symptoms were observed in the virus-eliminated rootstocks Beta and Riparia, which had been planted for 3 years and had not showed obvious symptoms in that time. Because these rootstocks were from the same source, and only several samples displayed ring spot symptoms and tested positive for GINV, this suggested that these samples may have been infected with GINV through insect vector transmission. Thus, to prevent the further spread of GINV and avoid losses in grape production, it is necessary to identify which insect species can transmit GINV in China. GINV has been reported to be transmitted by mites (Kunugi et al. 2000).

Due to frequent trade and grafting of the Eurasian grapevine materials, it is not unusual that $V$. vinifera $\mathrm{L}$. was infected with GINV at a higher incidence (30.1\%) than other grape varieties, similar to GLRaV-1 (Fan et al. 2015b). Owing to the obvious symptoms displayed by Beta and Riparia rootstocks, it is important to eliminate the GINVinfected rootstocks in a timely fashion in order to avoid the spread of GINV. Other common cultivars such as Thompson Seedless, Muscat Hamburg, Red Globe, and Cabernet Sauvignon also displayed ring spot and tested positive for GINV but not for GPGV and GFLV, suggesting that GINV may cause obvious symptoms in these common cultivars, in addition to the previously reported cultivars in Japan such as 'Takao', 'Kyoho', 'Pione', and 'Campbell Early' (Yoshikawa et al. 1997). Some major cultivars infected with GINV did not show any obvious symptoms, and this may be related to the characteristics of certain cultivars and the environment, which result in latent GINV symptoms in grapevines. Because of this potential latent status, it is very necessary to detect GINV before the exchange and propagation of grapevine cultivars so as to avoid unnecessary economic loss.

A phylogenetic analysis of the $\mathrm{CP}$ and MP sequences of the GINV isolates showed that all of the Chinese GINV isolates were divided into three groups. This was supported by the observation that the genetic distances among the three groups were higher than those within each group. Groups 1 and 2 were new groups detected in this study. It was observed that GINV isolates in groups 1 and 2 were widespread

Table 3. Prevalence and distribution of Grapevine berry inner necrosis virus (GINV) in grapevines from 15 different provinces and regions in China, as detected by reverse-transcription polymerase chain reaction using four primer pairs

\begin{tabular}{lcc}
\hline & \multicolumn{2}{c}{ Number of } \\
\cline { 2 - 3 } Province or region & Samples tested & Positive for GINV \\
\hline Liaoning & 48 & 19 \\
Yunnan & 1 & 0 \\
Hebei & 6 & 0 \\
Xinjiang & 19 & 10 \\
Shandong & 46 & 3 \\
Ningxia & 21 & 17 \\
Gansu & 8 & 2 \\
Sichuan & 1 & 1 \\
Anhui & 1 & 1 \\
Beijing & 21 & 14 \\
Guangxi & 6 & 1 \\
Shanghai & 6 & 2 \\
Tianjing & 5 & 0 \\
Chongqin & 4 & 0 \\
Zhejiang & 2 & 0 \\
Total & 195 & 70 \\
\hline
\end{tabular}



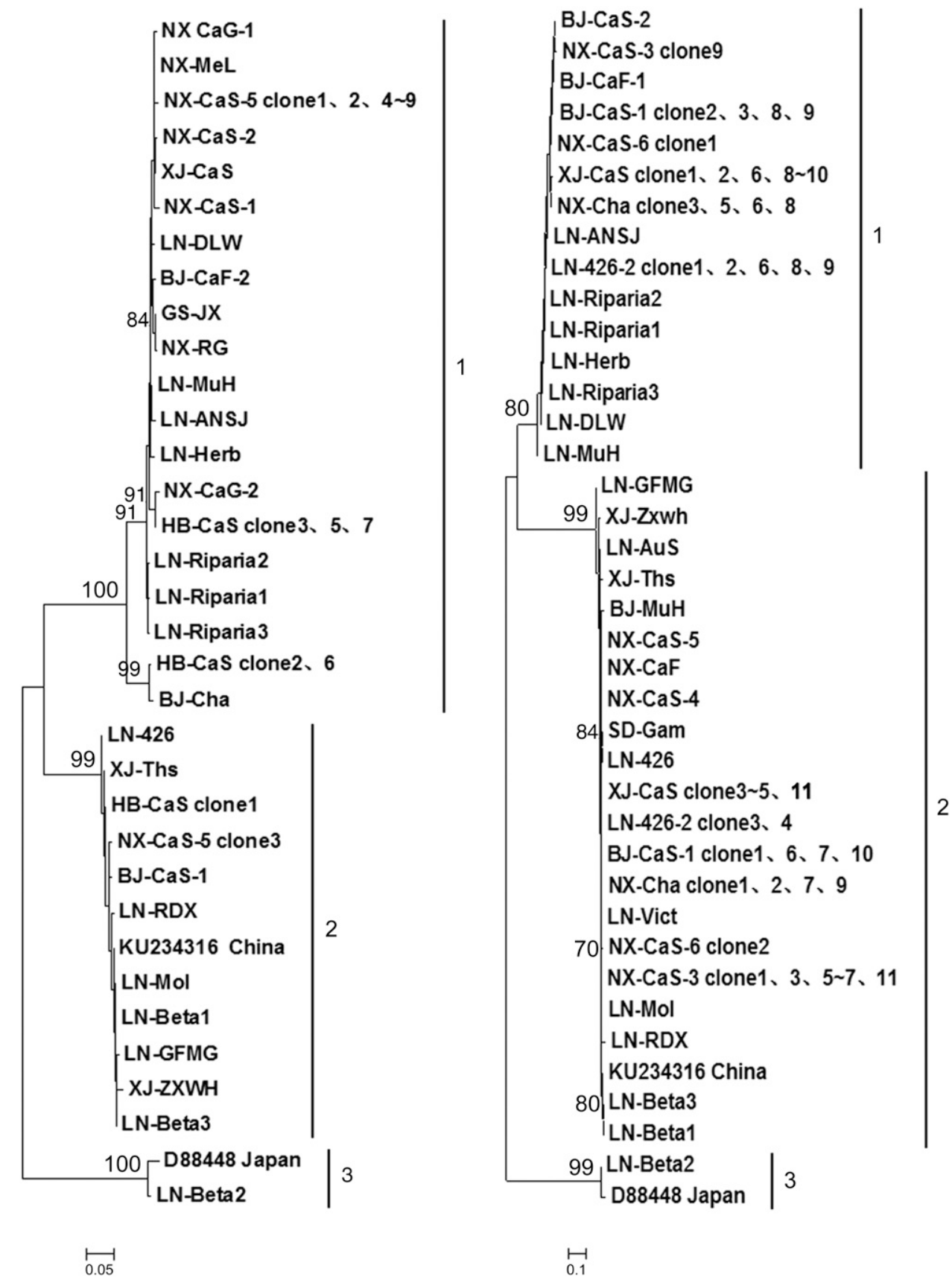

Fig. 2. Phylogenetic analysis of Grapevine berry inner necrosis virus isolates based on nucleotide sequences of the coat protein gene (left tree) and movement protein gene (right tree). Sequences reported by us are indicated by their isolate names. GINV isolate LN_BETA_RS (previously reported by us) and a Japanese isolate sequence are indicated by GenBank accession number, followed by their source. Trees were constructed using the neighbor-joining method. Numbers at the nodes indicate bootstrap support (1,000 replicates). Values below $70 \%$ are not shown.

among the grapevine samples in China and only the LN-Beta2 isolate, along with a Japanese isolate, was separated into group 3. The GINV variants belonging to groups 1 and 2 appear to be equally distributed in grapevines. However, for the individual grapevine, variants belonging to group 1 are the major variants in several tested grapevine samples. Several grapevine cultivars infected with the single GINV variant type in groups 1 or 2 had similar chlorotic mottling and ring spot symptoms. However, whether the three different GINV variant types cause different types of damage to grapevines requires further study. The results will also be helpful for the further study about the origin of GINV.

To the best of our knowledge, this represents the first report on the genetic diversity of GINV isolates, and also the prevalence and distribution of GINV isolates in China. Our results could help to improve the sanitary status of grapevine seedlings in China.

\section{Acknowledgments}

This work was supported by the earmarked fund of the China Agriculture Research System (CARS-30-bc-3). The authors declare that they have no competing interests.

\section{Literature Cited}

Fan, X. D., Dong, Y. F., Zhang, Z. P., Ren, F., Hu, G., and Zhou, J. 2015a. Detection and sequence analysis of Grapevine leafroll-associated virus 2 isolates from China. J. Phytopathol. 163:978-986.

Fan, X. D., Dong, Y. F., Zhang, Z. P., Ren, F., Hu, G. J., Li, Z. N., and Zhou, J. 2016a. First report of Grapevine Pinot gris virus from grapevines in China. Plant Dis. 100:540.

Fan, X. D., Dong, Y. F., Zhang, Z. P., Ren, F., Hu, G. J., and Zhu, H. J. 2013. First report of Grapevine virus E from grapevines in China. J. Plant Pathol. 95:659-668.

Fan, X. D., Hong, N., Dong, Y. F., Ma, Y. X., Zhang, Z. P., Ren, F., Hu, G. J., Zhou, J., and Wang, G. P. 2015b. Genetic diversity and recombination analysis of grapevine leafroll-associated virus 1 from China. Arch. Virol. 160:1669-1678. 
Fan, X. D., Hong, N., Zhang, Z. P., Ren, F., Hu, G. J., Li, Z. N., and Zhou J. 2016b. Identification of a divergent variant of grapevine berry inner necrosis virus in grapevines showing chlorotic mottling and ring spot symptoms. Arch. Virol. 161:2025-2027.

Farooq, A. B. U., Ma, Y. X., Wang, Z. Q., Zhuo, N., Xu, W. X., Wang, G. P., and Hong, N. 2013. Genetic diversity analyses reveal novel recombination events in Grapevine leafroll-associated virus 3 in China. Virus Res. 171: 15-21.

Hu, G. J., Dong, Y. F., Zhang, Z. P., Fan, X. D., Ren, F., and Zhu, H. J. 2014. Detection and sequence analysis of grapevine virus B isolates from China. Acta Virol. 58:180-184.

Hu, G. J., Dong, Y. F., Zhu, H. J., Zhang, Z. P., Fan, X. D., Ren, F., and Zhou, J. 2015. Molecular characterizations of two grapevine rupestris stem pittingassociated virus isolates from China. Arch. Virol. 160:2641-2645.

Kunugi, Y., Asari, S., Terai, Y., and Shinkai, A. 2000. Studies on the Grapevine berry inner necrosis virus disease. 2. Transmission of Grapevine berry inner necrosis virus by the grape erineum mite Colomerus vitis in Yamanashi. Bull. Yamanashi Fruit Tree Exp. Stn. 10:57-63.

Liu, M. H., Li, M. J., Qi, H. H., Guo, R., Liu, X. M., Wang, Q., and Cheng, Y. Q. 2013. Occurrence of grapevine leafroll-associated viruses in China. Plant Dis. 97:1339-1345

Lyu, M. D., Li, M. J., Li, J., Li, X. M., and Cheng, Y. Q. 2013. First report of Grapevine leafroll-associated virus 7 in two native grape varieties in China. Plant Dis. 97:150.

Lyu, M. D., Li, X. M., Guo, R., Li, M. J., Liu, X. M., Wang, Q., and Cheng, Y. Q. 2014. Prevalence and distribution of Grapevine leafroll-associated virus 7 in China detected by an improved reverse transcription polymerase chain reaction assay. Plant Pathol. 63:1168-1176.

MacKenzie, D. J., Mclean, M. A., Mukerji, S., and Grenn, M. 1997. Improved RNA extraction from woody plants for the detection of viral pathogens by reverse transcription-polymerase chain reaction. Plant Dis. 81:222-226.
Martin, D. P., Lemey, P., Lott, M., Moulton, V., Posada, D., and Leveuvre, P. 2010. RDP3: A flexible and fast computer program for analyzing recombination. Bioinformatics 26:2462-2463.

Nolasco, G., Mansinho, A., Santos, M. T., Soares, C., Sequeira, Z., Correia, P. K. and Sequeira, O. A. 2000. Large scale evaluation of primers for diagnosis of rupestris stems pitting associated virus-1. Eur. J. Plant Pathol. 106:311-318.

Pei, G. Q., Dong, Y. F., Zhang, Z. P., and Fan, X. D. 2010. First Report of Grapevine leafroll-associated virus 4 and 5 in Grapevines in China. Plant Dis. 94:130.

Tamura, K., Stecher, G., Peterson, D., Filipski, A., and Kumar, S. 2013. MEGA6: Molecular evolutionary genetics analysis version 6.0. Mol. Biol. Evol. 30: 2725-2729.

Terai, Y., Kunugi, Y., and Yanase, H. 1993. A new virus disease, grapevine berry inner necrosis with natural spread in Japan. Pages 77-78 in: Extended Abstracts 11th Meeting ICVG. P. Gugerli, ed. Federal Agricultural Research Station of Changins, Montreux, Switzerland

Terlizzi, F., Li, C., Ratti, C., Qiu, W., Credi, R., and Meng, B. 2011. Detection of multiple sequence variants of Grapevine rupestris stem pitting-associated virus using primers targeting the polymerase domain and partial genome sequencing of a novel Variant. Ann. Appl. Biol. 159:478-490.

Walsh, H. A., and Pietersen, G. 2013. Rapid detection of Grapevine leafrollassociated virus type 3 using a reverse transcription loop-mediated amplification method. J. Virol. Methods 194:308-316.

Wang, Z. Q., Hong, N., Liu, Y., Xu, W. X., and Wang, G. P. 2011. Genetic variability and population structure of Grapevine virus A in China based on the analysis of its coat protein gene. Can. J. Plant Pathol. 33:227-233.

Yoshikawa, N., Iida, H., Goto, S., Magome, H., Takahashi, T., and Terai, Y. 1997. Grapevine berry inner necrosis, a new trichovirus: Comparative studies with several known Trichoviruses. Arch. Virol. 142:1351-1363.

Zhou, J., Fan, X., Dong, Y., Zhang, Z., Ren, F., and Hu, G. J. 2015. Detection and genetic variation analysis of grapevine fanleaf virus (GFLV) isolates in China Arch. Virol. 160:2661-2667. 